\title{
KEARIFAN LOKAL MASYARAKAT LAMALERA: Sebuah Ekspresi Hubungan Manusia Dengan Laut
}

\author{
Nendah Kurniasari dan Elly Reswati \\ Balai Besar Penelitian Sosial Ekonomi Kelautan dan Perikanan \\ JI. KS. Tubun Petamburan VI Jakarta 10260 \\ Telp. (021) 53650162, Fax. (021)53650159 \\ Diterima 11 Mei 2011- Disetujui 29 November 2011
}

\begin{abstract}
ABSTRAK
Makalah ini bertujuan melihat kearifan lokal yang dibentuk oleh sebuah masyarakat nelayan dilihat dari perspektif psikologi lingkungan. Makalah ini merupakan studi literatur, dimana informasi diperoleh dengan cara mengkaji literatur yang terkait dengan teori-teori adaptasi lingkungan, kearifan lokal serta kehidupan masyarakat Lamalera. Kearifan lokal yang berkembang di masyarakat Lamalera mengenai norma berburu paus telah berusia ratusan tahun. Kearifan itu merupakan perbauran yang kental antara tradisi dan ajaran Katolik. Kearifan yang muncul tidak hanya menjaga kelestarian dan kesimbangan ekosistem laut namun juga menjaga keseimbangan dalam berhubungan dengan sesama warga masyarakat. Keseimbangan alam tersebut terancam ketika Pemerintah Daerah mengeluarkan ijin untuk penambangan emas. Kearifan lokal yang muncul sabagai reaksi dari adanya stimulus ini adalah penolakan terhadap penambangan emas di Lamalera dengan alasan akan merusak keseimbangan ekosistem yang mengakibatkan terputusnya ikatan mereka dengan para leluhur yang selama ini telah menjaganya.
\end{abstract}

Kata kunci: kearifan lokal, Lamalera, paus, masyarakat pesisir

\section{PENDAHULUAN}

Kearifan lokal dalam beberapa dasawarsa terakhir ini mendapatkan perhatian besar dari berbagai kalangan terutama lembaga-lembaga swadaya masyarakat dan pemerhati lingkungan. Beberapa pemerintah daerah pun mulai menggali kearifan lokal yang dimiliki daerahnya. Ketertarikan ini disebabkan karena semakin dominannya dampak dari modernisasi yang melahirkan konsekuensi-konsekuensi yang merugikan. Konsekuensi dari eksploitasi sumber daya alam yang tak terkendali akan mengakibatkan degradasi lingkungan hidup, tidak terkecuali lingkungan laut.

Arus modernisasi dan globalisasi yang melanda setiap daerah sampai ke pelosok-pelosok negeri, menjadikan pembuat kebijakan dan para pemerhati lingkungan mencoba berbagai cara meminimalisasi kemungkinan dampak yang muncul. Salah satu harapan tertumpu pada kearifan-kearifan terhadap lingkungan yang dimiliki oleh masing-masing daerah.

Kearifan lokal diharapkan dapat mengatasi ancaman degradasi lingkungan karena kearifan lokal merupakan dimensi budaya dan sosial yang lahir dalam kehidupan bermasyarakat yang telah berlangsung secara turun temurun. Kearifan lokal dapat menjelma dalam berbagai bentuk seperti ide, gagasan, nilai, norma dan peraturan dalam ranah kebudayaan, sedangkan dalam kehidupan sosial dapat berupa sistem religius, sistem dan organisasi kemasyarakatan, sistem pengetahuan, sistem mata pencaharian hidup, dan sistem teknologi dan peralatan (Koentjaraningrat, 1964).

Identifikasi kearifan lokal masyarakat nelayan harus lebih difokuskan kepada permasalahan yang menyangkut isu global dan sekaligus mempunyai pengaruh yang cukup besar bagi keberlangsungan hidup masyarakat local (Coremap, 2005). Salah satu contoh kearifan lokal yang berkaitan dengan dua hal tersebut adalah prosesi penangkapan paus yang dilakukan oleh masyarakat Lamalera. Di satu sisi paus merupakan mamalia yang termasuk dalam daftar hewan yang dilindungi karena jumlahnya yang semakin menyusut. Namun di lain pihak, paus bagi masyarakat Lamalera merupakan sumber kehidupan utama. Hans (2008) mengatakan bahwa masyarakat Lamalera menyadari bahwa tanpa ikan paus mereka tidak bisa hidup. Karena merupakan sumber kehidupan inilah, maka dengan kerifan lokal yang telah ada sejak ratusan tahun, mereka berusaha melestarikan paus dengan menjaga keseimbangan ekosistem laut dan peisisir.

Penggambaran kehidupan nelayan Lamalera yang sarat akan sejumlah kearifan lokal membawa pesan bagi masyarakat lain dalam rangka menyelesaikan permasalahan-permasalahan lingkungan di daerahnya, sehingga generasi mendatang akan menerima warisan alam dengan kondisi yang semestinya mereka terima.

\section{PERILAKU MANUSIA DAN KEARIFAN LOKAL}

Psikologi lingkungan merupakan bagian bari ilmu psikologi yang mempelajari hubungan antara manusia dengan lingkungannya. Lebih jelas Veitch dan Arkkelin (1995) mendefinisikan Psikologi Lingkungan sebagai a behavioral science that investigates, with an eye toward enhancing, the interrelationships between the physical environment and human behavior. Pengertian senada disampaikan oleh Holahan (1982), bahwa psikologi lingkungan adalah bidang psikologi yang meneliti hubungan timbal balik antara lingkungan fisik dengan tingkah laku dan pengalaman manusia. Kedua 
pengertian tersebut memposisikan prilaku manusia dan kondisi lingkungan sebagai sentral dalam pembahasan permasalahan lingkungan.

Perilaku manusia sebagaimana dikemukakan dalam Gestalt disebabkan oleh proses-proses persepsi, sehingga mempelajari proses persepsi dan kognisi manusia menurutnya lebih penting daripada mempelajari prilaku yang tampak (overt behaviour). Sementara itu teori medan dari Kurt Lewin merupakan teori yang menerangkan hubungan manusia dengan alam. Lewin mengemukakan formula $B=f(E, O)$, bahwa perilaku manusia merupakan fungsi dari lingkungan dan organisme. Teori ekologi ini mempunyai asumsi dasar yaitu a) prilaku manuisa terkait dengan koteks lingkungan, b) interaksi timbal balik yang menguntungkan antara manusia dengan lingkungan, c) interaksi manusia-lingkungan bersifat dinamis, dan d) interaksi manusia - lingkungan terjadi dalam beberapa level dan tergantung pada fungsi. Salah satu teori yang didasarkan pada pandangan ekologis adalah behaviour setting (seting perilaku).

Teori behaviour setting mengandung premis utama yaitu kesesuaian antara rancangan lingkungan dengan perilaku yang diakomodasikan dalam lingkungan tersebut. Sehingga, dimungkinkan adanya pola-pola perilaku yang telah tersusun yang dikaitkan dengan setting tempat. Pada dasarnya pola-pola ini merupakan bagian dari proses adaptasi terhadap setting yang ada. Teori ini lebih menekankan pada uniformitas atau perilaku kolektif. Hubungan antara manusia-lingkungan lebih dijelaskan dari sisi sifat atau karakteristik sosial seperti kebiasaan, aturan, aktifitas tipikal, dan karakteristik fisik.

Dalam konteks kehidupan sosial, maka teori ekologis ini merupakan pendekatan yang dapat menerangkan munculnya kearifan lokal dari sudut pandang psikologi lingkungan. Namun, teori-teori yang lain bermanfaat untuk menerangkan dinamika psikis sosial masyarakat dalam menghadapi perubahanperubahan lingkungan. Menurut Barker (dalam Sarwono, 1992) tingkah laku tidak hanya ditentukan oleh lingkungan, tetapi kedua hal tersebut saling menentukan dan tidak dapat dipisahkan. Hubungan tingkah laku dan lingkungan ini seperti dua jalan atau interdependensi ekologi. Pola adaptasi yang mengandung karakteristik sosial di atas, akan membentuk kepribadian yang khas dari nelayan tersebut. Ketika pola adaptasi ini dilakukan secara kolektif maka akan mencerminkan kepribadian kolektif atau kepribadian masyarakat. Kepribadian ini kemudian disepakati dalam bentuk norma-norma yang harus ditaati secara turun temurun membentuk sebuah kearifan lokal. Dengan demikian, kearifan lokal merupakan produk dari hubungan perilaku masyarakat terhadap alam dan sebaliknya hubungan alam terhadap perilaku masyarakatnya. Berrdasarkan uraian tersebut, kearifan lokal terhadap lingkungan memunculkan prilaku kolektif dari suatu komunitas dalam berinteraksi dengan ekosistemnya agar keseimbangan ekosistem selalu terjaga.

Kearifan lokal terhadap lingkungan merupakan norma-norma yang terkait dengan pengetahuan, teknologi, kepercayaan dan kelembagaan yang dipraktekan oleh suatu komunitas/masyarakat selama bertahun-tahun dalam mengelola sumberdaya alam yang ada. Bentuk kearifan lokal yang dimiliki suatu daerah akan berbeda dengan daerah lainnya sesuai dengan setting lingkungan yang mereka hadapi. Veitch dan Arkkelin (1995) mengatakan bahwa dengan mengetahui setting tempat maka dapat diprediksi perilaku atau aktivitas yang terjadi. Setting lingkungan yang spesifik akan menyebabkan perbedaan pengetahuan seseorang dalam memaknai pengaruh lingkungan terhadap kehidupannya.

Kearifan lokal merupakan proses pemaknaan suatu komunitas terhadap lingkungannya. Kearifan Lokal dalam bahasa asing sering dikonsepsikan sebagai kebijaksanaansetempat(localwisdom)atau pengetahuan setempat (local knowledge) atau kecerdasan setempat (local genious), merupakan pandangan hidup, ilmu pengetahuan, dan berbagai strategi kehidupan yang berwujud aktivitas yang dilakukan oleh masyarakat setempat dalam menjawab berbagai masalah dalam memenuhi kebutuhan mereka. Kearifan lokal di berbagai wilayah di Nusantara merupakan kekayaan budaya yang perlu diangkat ke permukaan sebagai bentuk jati diri bangsa.

Pemaknaan terhadap lingkungan ini erat kaitannya dengan perkembangan kognisi mereka tentang lingkungan. Dengan kata lain, sejauhmana kearifan lokal ini dapat bertahan sangat tergantung kepada sajauh mana mereka bisa mempertahankan persepsi terhadap lingkungan yang sekarang ada dari terpaan arus modernisasi dan globalisasi yang sering tidak berpihak terhadap lingkungan. Pembahasan kearifan lingkungan yang terjadi di Lamalera memberikan pelajaran bagaimana seharusnya kita menyikapi lingkungan dan bagaimana seharusnya menghadapi tantangan yang mengancam keseserasian alam.

\section{KONDISI GEOGRAFIS LAMALERA}

Pembahasan mengenai kondisi geografis perlu dilakukan dalam psikologi lingkungan. Sebagaimana yang dikatakan Tonybee dalam Veitch dan Arkkelin, 1995 bahwa lingkungan (atau secara labih spesifik topografi, iklim, vegetasi, ketersediaan air, dan sebagainya) adalah tantangan bagi penduduk yang tinggal di daerah tersebut. Tantangan lingkungan yang ekstrim akan merusak peradaban, sementara tantangan yang terlalu kecil akan mengakibatan stagnsi kebudayaan. Jadi setting geografis lingkungan akan memberi kesempatan mayarakat penghuninya untuk membuat perdaban guna memenuhi kebutuhan dan upaya mempertahankan diri. 
Lamalera merupakan sebuah kampung yang terletak di Kabupaten Lembata Nusa Tenggara Timur (NTT). Secara terminologi kata "Lamalera" menurut bahasa Lamaholot yaitu bahasa daerah di kawasan Flores Timur, berasal dari kata lama berarti piringan atau cakram dan lera berarti matahari, sehingga Lamalera berarti pinggiran/cakram matahari (Haryadi, 2007). Haryadi pun mengungkapkan bahwa dari tiga puluh jenis cetacean (nama kolektif paus dan lumba-lumba di Indonesia, empat belas diantaranya bermigrasi melewati Sawu. Penduduk Lamalera terkenal di seluruh dunia sebagai pemburu paus (koteklema) yang unik, karena berburu hanya dengan menggunakan peralatan yang serba tradisional. Tidak hanya peralatannya saja yang spesifik, namun norma-norma yang dilakukan menjelang perburuan, pada saat perburuan dan setelah memperoleh hasil buruan sangat unik. Berikut ini merupakan gambaran kearifan lokal masyarakat Lamalera terhadap lingkungan serta pemaknaannya dalam kacamata psikologi lingkungan.

\section{KEARIFAN LOKAL: Ekspresi Nelayan terhadap Ekosistem Laut}

Masyarakat Lamalera merupakan masyarakat yang memandang laut dan darat mempunyai hubungan pengaruh mempengaruhi secara timbal balik. Hal ini senada dengan yang dikatakan Barker dalam Sarwono (2005) bahwa perilaku dan lingkungan merupakan dua hal yang saling menentukan dan tidak dapat dipisahkan. Apa yang dilakukan seseorang di darat akan mempengaruhi apa yang akan terjadi di laut, begitu pun sebaliknya. Pengetahuan mereka terhadap hubungan laut dan alam memunculkan persepsi bahwa prilaku yang sesuai dengan norma yang dianut harus selalu dilakukan agar ekosistem selalu stabil dan dapat dimanfatkan secara berkelanjutan. Keyakinan ini pula yang menjadikan prosesi penangkapan paus yang merupakan mata pencaharian utama di Lamalera mengandung nilai dan norma yang khas.

Masyarakat Lamalera merupakan masyarakat dengan tradisi yang dipengaruhi oleh ajaran Katolik. Hal ini dimungkinkan karena daerah Lamalera termasuk salahsatu daerah penyebaran Katolik pertama di Indonesia yang dibawa oleh bangsa Portugis pada abad ke 16 Masehi. Haryadi (2007) mengungkapkan bahwa masyarakat melakukan berbagai ritual yang berkaitan dengan penangkapan paus, diantaranya adalah perayaan misa arwah yang dilaksanakan di pantai depan Kapel Santo Petrus yang dipimpin oleh seorang Pastor. Misa dilanjutkan keesokan harinya dengan misa lefa dan pemercikan air suci ke perahu-perahu. Sedangkan upacara ceremoti dihadiri oleh seluruh komponen kampung Lamalera untuk membicarakan seluruh persoalan kampung terutama persoalan perburuan dengan berbagai tahapan yang mesti dilaksanakan dalam perburuan itu.
Dalam perspektif psikologi, agama mempunyai pengaruh yang besar dalam setiap perilaku yang muncul. Seperti yang dikatakan oleh Sarlito (2005) bahwa agama hampir selalu merupakan acuan utama dalam hampir setiap perilaku, baik individual maupun kelompok dalam setiap satuan etnik, budaya, kelompok, keluarga dan sebagainya. Dasar pengetahuan agama merupakan spirit yang cukup besar dalam menjaga keberlangsungan karifan-kearifan lokal, dan sering kali pengetahuan agama pula yang memungkinkan munculnya kearifan. Pemaknaan lingkungan yang kaya akan nilai-nilai keterikatan dengan alam ditunjukkan dalam prosesi penangkapan paus. Penangkapan paus oleh nelayan Lamalera dilakukan dengan menggunakan peralatan yang sederhana yaitu layar, tali (yang terbuat dari benang kapas, daun gebang dan serat kulit waru), pancing, tempuling atau harpun, peledang (perahu) dari kayu, sampan, galah tempat menamcapkan harpun untuk menombak, alat untuk menggayung air, gentong air, dan faje (alat untuk mendayung) (JPIC OFM, 2008; Hardianto, 2008: Hans, 2008). Hal ini sangat berbeda sekali dengan yang dilakukan oleh Jepang, dimana mereka menggunakan peralatan yang merusak lingkungan. Penangkapan paus ini pun bertujuan hanya untuk konsumsi bukan untuk keperluan niaga yang bertujuan mendapatkan hasil yang sebesar-besarnya.

Selain teknik penangkapan, masyarakat pun mengatur jenis dan kondisi paus yang dapat ditangkap yaitu paus sperm yang dalam kondisi tidak hamil. Paus biru yang dilindungi bukan menjadi sasaran mereka. Berdasarkan mitologi yang mereka yakini secara turun temurun, paus biru pernah berjasa menolong orang Lamalera yang mengalami kecelakaan di laut. Oleh karenanya, paus biru harus dihormati dan tidak boleh ditangkap.

Kasus diatas menunjukkan bahwa persepsi masyarakat terhadap lingkungan sangat dipengaruhi oleh setting di masa lalu. Seberapa lama persepsi itu dapat bertahan dalam sebuah komunitas sangat tergantung pada bagaimana upaya menurunkan pengetahuan lingkungan tersebut kepada generasi selanjutnya, selain itu sangat tergantung pada sejauhmana persepsi itu dapat mengelaborasi novel environment sebagai akibat dari intervensi modernisasi.

Masyarakat Lamalera tidak hanya mempunyai kearifan terhadap sumber daya alam, namun mereka juga mempunyai kearifan yang sangat mulia terhadap sesamanya. Mereka menempatkan para janda, fakir miskin dan anak yatim piatu pada posisi utama dalam pembagian hasil laut. Hal ini menunjukkan tingginya naluri prososial yang dimiliki oleh masyarakat Lamalera. Haryadi (2007) mengatakan bahwa tubuh koteklema itu sudah mempunyai peta khusus untuk pembagian, misalnya selain daging dan lemaknya, para pemilik kapal berhak mendapatkan bagian dari jantung, sayatan bagian ekor juga diberikan kepada matros yang ikut membunuh paus. Semua warga mengetahui bagian 
mana yang sudah menjadi haknya, dan hak itu diatur berdasarkan perannya dalam perburuan paus tersebut serta perannya dalam hubungan sosial.

Kesahajaan sangat tercermin dalam mekanisme pasar yang dilakukan oleh masyarakat Lamalera. Mereka masih mempertahankan sistem barter dalam memperoleh barang kebutuhan. Brotoseno (2010) mengatakan bahwa di atas pegunungan ada desa yang dinamakan (Wulandoni), yang setiap hari Sabtu sering dilakukan pasar barter. Banyak pendatang membawa barang seperti jagung, pisang sampai bahan bahan kebutuhan rumah tangga yang ditukarkan dengan daging paus. Beberapa nelayan mungkin menjalani sistem ini secara implisit, artinya barter hanyalah bagian dari aktivitas yang telah dilakukan secara turun temurun, namun jika dicermati lebih eksplisit terlihat bahwa melalui sistem barter masyarakat Lamalera terjaga dari dampak negatif pertarungan ekonomi global yang sangat ditentukan oleh naik turunnya nilai tukar mata uang. Sistem barter mengandung nilai-nilai yang sangat arif yang ingin di jaga oleh masyarakat Lamalera.

\section{ANCAMAN TERHADAP KEARIFAN LOKAL: Persepsi dan Stress Lingkungan}

Psikologi lingkungan mendefinisikan persepsi sebagai proses pengamatan individu terhadap lingkungannya yang diolah secara kognitif. Dalam kasus ini, persepsi masyarakat Lamalera adalah proses pengamatan yang dilakukan masyarakat terhadap lingkungannya. Veitch dan Arkkelin (1995) mengatakan bahwa persepsi merupakan basis rujukan sikap dan tingkah laku. Sementara itu Bell dalam Sarwono (1992) menggambarkan proses terbentuknya persepsi yaitu dimulai dengan proses mempresepsikan objek fisik sebagai sumber stimulus oleh individu. Pada batas optimal maka persepsi tersebut akan berakhir pada kondisi homeostatis. Sebaliknya, pada kondisi diluar batas yang terjadi adalah stress yang memerlukan koping untuk mengatasinya, jika berhasil akan terbentuk adaptasi dan menghasilkan efek lanjutan. Sementara itu koping yang tidak berhasil akan berdampak pada stress yang terus berlanjut dan menimbulkan efek lanjutan yang lain. Koping yang berhasil akan menghasilkan dua bentuk penyesuaian, yaitu penyesuaian individu dengan lingkungannya (adaptasi) atau penyesuaian lingkungan pada diri indivisu (adjustment).

Daerah Lembata merupakan daerah yang banyak menyimpan emas. Potensi ini sudah disadari oleh masyarakat setempat sejak ratusan tahun yang lalu, namun bagi mereka emas yang ada di perut bumi merupakan warisan dari leluhur yang harus dijaga dan dipertahankan. Keseimbangan ekosistem Lamalera kemudian diintervensi oleh munculnya ijin dari Pemerintahan Kabupaten Lembata kepada PT Merukh untuk melakukan tambang emas di daerah Lembata pada tahun 2005. Setiap proses penambangan tentu akan menguras lahan dan sumber air. Hal ini sangat merugikan Lembata, karena Lembata tergolong daerah kering dan gersang dan air merupakan pembatas utama keselamatan warga lembata. Sehingga izin ini sangat mengancam keselamatan masyarakat lembata (Jatam, 2008).

Pemerintah Kabupaten Lembata tetap pada pendiriannya untuk meneruskan rencana penambangan dengan mengadakan sosialisasi yang lebih mendalam tentang keuntungan yang akan didapat dari penambangan emas ini. Hal ini menimbulkan berbagai macam tekanan baik tekanan terhadap ancaman terganggunya keseimbangan ekosistem juga tekanan terhadap psikis masyarakat Lamalera. Tekanan-tekanan ini dalam istilah psikologi disebut stress. Stress terdiri dari tiga komponen yaitu stressor, proses dan respon (Veitch dan Arkelin, 1995). Dalam kasus Lembata, izin penambangan emas merupakan stressor, ia merupakan stimulus yang mengancam kesejahteraan masyarakat Lamakera. Adanya stimulus ini mendorong masyarakat Lamalera untuk memikirkan dan mempertimbangkan konsekuensi-konsekuensi yang akan diterima jika menolak atau sepakat dengan perijinan tersebut.

Penolakan terhadap ijin penambangan tersebut, bukan karena alasan tidak pahamnya mereka terhadap nilai yang terkandung dalam emas tersebut yang dapat meningkatkan kesejahteraan, namun persepsi "kesejahteraan" antara pemerintah dengan masyarakat Lamalera sangat berbeda. Kesejahteaan bagi masyarakat Lamalera bukanlah dinilai dari tingginya penghasilan, bagi mereka 'sejahtera' adalah hidup selaras dengan alam dan dapat memberikan alam sebagai warisan kepada generasi mendatang dalam bentuk yang seharusnya mereka terima.

Intervensi yang dilakukan Pemerintah Kabupaten dengan memberikan izin kepada PT Merukh terhadap lingkungan Lamalera sudah mengakibatkan stress mental yang luar biasa bagi masyarakat Lamalera. Agar tidak terjadi proses penambangan maka masyarakat Lamalera mengadakan koping dengan mengadakan penolakan melalui surat penyataan bersama yang disampaikan kepada Pemda setempat, aksi-aksi yang melibatkan massa, ritual dan sumpah adat serta penyampaian alternatif cara pemberdayaan yang dapat dilakukan pemerintah dalam mensejahterakan masyarakat Lamalera.

Ditinjau dari perspektif psikologi lingkungan, penolakan terhadap penambangan emas yang dilakukan oleh masyarakat Lamalera lebih didasari oleh persepsi mereka terhadap bumi dan laut serta kandungan di dalamnya. Bumi dan laut bagi mereka merupakan pengikat antara mereka dengan leluhur. Penjagaan ini merupakan wujud penghormatan mereka terhadap leluhur. Pengrusakan terhadap bumi dan laut akan menyebabkan kemarahan leluhur dan terputusnya ikatan dengan leluhur (Jatam, 2008). Selain itu, tercemarnya 
laut akibat penambangan akan menyebabkan hilangnya paus dari perairan Lamalera. Paus merupakan hewan yang sensitif, mereka akan meninggalkan laut yang tercemar untuk bermigrasi mencari tempat yang baru. Persepsi inilah kemudian melahirkan berbagai kearifan lokal diantaranya adalah penolakan terhadap rencana tambang emas tersebut. Karena dengan tindakan itu, masyarakat Lamalera berusaha menjaga ikatan yang serasi antara manusia dengan alam agar terjadi kelestarian dan keserasian yang akan mendatangkan kedamaian dan kecukupan pangan.

\section{KESIMPULAN}

Mayoritas penduduk Lamalera menggantungkan hidupnya dari hasil laut terutama paus, sehingga pengetahuan mereka tentang lingkungan selalu berhubungan dengan laut dan paus. Pengetahuan tersebut memunculkan persepsi tersendiri terhadap alam, yang kemudian membuat perilaku yang khas dari masyarakat Lamalera dalam berinteraksi dengan alam. Pola perilaku yang bersifat lokalitas ini menumbuhkan kearifan tradisional yang spesifik. Kearifan masyarakat Lamalera memberikan kontribusi yang besar dalam menjaga keberlanjutan sumber daya alam. Penolakan masyarakat terhadap aktifitas penambangan merupakan bentuk kearifan dalam mempertahankan keseimbangan ekosistem demi keberlanjutan kehidupan dimasa yang akan datang.

\section{DAFTAR PUSTAKA}

Brotoseno, I. 2010. Lamalera. http://dunialaut. com/?p=574. Diakses pada tanggal 11 Juli 2011.

COREMAP II. 2005. Kajian Kearifan Lokal masyarakat di Desa Sabang Mawang, Sededap dan Pulau Tiga Kecamatan Bunguran Barat Kabupaten Natuna, Propinsi Kepulauan Riau. Kementerian Kelautan dan Perikanan. Jakarta.
Hans. 2008. Penangkapan Paus di Lamalera Perhatikan Aspek Konservasi. http://www.nttonlinenews. com/ Diakses pada tanggal 6 Februari 2009.

Haryadi, R. 2007. Cakram Matahari Memburu Kotekelema. Gatra Nomor 28. Jakarta.

Holahan C.J. 1982. Environmental Psychology. New York: Random House.

JATAM. 2008. Membangun Lembata Tanpa Tambang Emas. http://www.jatam.org/content/ view/393/1/. Diakses pada tanggal 6 Februari 2009.

2008. Membaca Penolakan Warga Atas Rencana Penambangan Emas di Kabupaten Lembata NTT Sebagai Wujud Akal Sehat Rakyat dalam Membela Kehidupan dan Pembangunan Berkelanjutan di Kabupaten Lembata Oleh: Justice, Peace, and Integrity of CreationOrdo Fratrum Minorum (JPIC-OFM) Indonesia. http://www.scribd.com/doc/52753119/AlasanMerusak-Lingkungan. Diakses Pada tanggal 11 Juli 2011.

Koentjaraningrat. 1964. Masyarakat Desa Masa Kini. Balai Penerbitan Fakultas Ekonomi UI, Jakarta.

Prasetio, B. 2008. Perburuan Paus di Lamalera: Simbol Keseimbangan Masyarakat Tradisional dengan alam.http://www.nttonlinenews.com/ntt/ index.php?view=article\&id. Diakses pada tanggal 11 Juli 2011.

Sarwono, S.W. 1992. Psikologi Lingkungan. P.T. Gramedia Widiasarana Indonesia. Jakarta. 